ISSN 0258-7122

Bangladesh J. Agril. Res. 34(3) : 531-536, September 2009 Short Communication

\title{
EFFECT OF SOWING TIME AND SPACING ON LETTUCE SEED PRODUCTION IN HILLY REGION
}

\author{
Z. A. FIROZ ${ }^{1}$, M.S. ALAM², M. S. UDDIN ${ }^{3}$ AND S.A. KHATUN ${ }^{4}$
}

An experiment was conducted at the Hill Agricultural Research Station, Khagrachari from November 2002 to May 2003 to find out the effect of sowing time (10, 20, 30 November and 10, 20, and 30 December) and spacing (50 x 30 $\mathrm{cm}$ and $50 \mathrm{x} 45 \mathrm{~cm}$ ) on lettuce seed production. Maximum lettuce seed yield (770 $\mathrm{kg} / \mathrm{ha}$ ) was found from 10 November sowing with $50 \times 45 \mathrm{~cm}$ spacing followed by same sowing time with $50 \times 30 \mathrm{~cm}$ and 20 November with both spacings. There was a trend to decrease seed yield with the advance of sowing time irrespective of spacing. Germination (\%) and other quality also showed satisfactory result in the same treatment.

Lettuce is one of the most important vegetable crops in temperate countries. However, it occupies an important position for its cultivation in tropical and subtropical countries also. Lettuce occupies the largest area among salad crops and thus it is the most important salad crop of the world (Bose, 1990). It is rich in vitamin A and C and minerals like calcium and iron (Aykroyd, 1963). Among the various factors, sowing time and plant spacing are very important factor for lettuce seed production and seed quality. The effect of sowing time on growth and seed yield of lettuce was reported by many authors (Gray et al., 1988; Karim et al., 2000 and Sajjan et al., 1993). Ryder (1998) reported that lettuce showed better performance at that time when temperature is $18-25^{\circ} \mathrm{C}$ at day and $10-15^{\circ} \mathrm{C}$ at night. Verker and Spitters (1973) stated that the time when temperature is very high is not favourable for lettuce seed production.

Plant spacing is an important factor for lettuce seed production. The improper plant spacing may cause either too dense or too sparse population resulting in the reduction of lettuce yield. But optimum plant density ensures the plants to grow uniformly and properly through efficient utilization of moisture, nutrients, light and thus causes to produce maximum yield of lettuce. Planting with proper spacing increases yield, quality, and size of seed. In Chittagong hilly region, temperature is comparatively low in winter season and this low temperature remains for long time which is fevourable for lettuce seed production. But reports in this aspect are very scanty on lettuce production in hilly areas of Bangladesh. The present investigation was, therefore, undertaken o find out the effect of planting time and plant spacing on lettuce seed production in the hilly region.

\footnotetext{
${ }^{1}$ Senior Scientific Officer (Hort.), Agricultural Research Station, Raikhali, Chandraghona, Rangamati, ${ }^{2}$ Scientific Officer (Hort.), Hill Agricultural Research Station, Khagrachari, ${ }^{3}$ Principal Scientific Officer, Regional Agricultural Research Station, Hathazari, ${ }^{4}$ Department of Biotechnology, BAU, Mymensingh.
} 
The experiment was carried out at the Hill Agricultural Research Station, Khagracahri during the period from November 2002 to May 2003. The experiment was conducted in hill valley and the soil status was given in Table 1. The treatment consisted of six planting times viz., 10, 20, 30 November and 10, 20, 30 December and two spacings viz., $50 \times 45 \mathrm{~cm}$ and $50 \times 30 \mathrm{~cm}$. The experiment was conducted in a split plot design where sowing time was given in main plot and plant spacing in sub plot. There were three replications. The unit plot size was $3.6 \times 1.0 \mathrm{~m}$. Lettuce seeds were directly sown in the plot. Fertilizers were applied at the rate of 200, 75, $75 \mathrm{~kg} / \mathrm{ha}$ Urea, TSP, and MP, respectively. Cowdung was used @ 10 t/ha during land preparation. The experiment was conducted in irrigated condition. Intercultural operations were done as and when necessary. Harvesting was started from 20 December and continued upto 10 March 2003. Data on plant height, days to flowering and yield contributing characters were recorded from ten selected plants but seed yield was recorded on plot basis. Collected data were statistically analyzed by F-test and means were compared by DMRT test.

Table 1. Physio-chemical properties of $0-20 \mathrm{~cm}$ topsoil at the experimental plot.

\begin{tabular}{l|l}
\hline \multicolumn{1}{c|}{ Soil characteristics } & \multicolumn{1}{c}{ Analytical value } \\
\hline Texture class & Clay loam \\
Organic matter (\%) & 5.2 \\
Total N (\%) & 1.35 \\
Exchangeable calcium (meq/1 00 g soil) & 1.09 \\
Exchangeable magnesium (meq/100 g soil) & 0.50 \\
Exchangeable potassium (meq/100 g soil) & 0.19 \\
Available P (ppm) & 4.2 \\
Available S (ppm) & 10.0 \\
Available Cu (ppm) & 2.2 \\
Available Iron (ppm) & 170.0 \\
Available Zinc (ppm) & 1.2 \\
Available boron (ppm) & 0.15 \\
Available manganese (ppm) & 13.0
\end{tabular}

The sowing time showed significant effects on all the parameters studied except 1000-seed weight (Table 2). The shortest time (76 days) for first flowering was required in 20 December which showed significant variation with all other treatments. Longest time (84) days to first flowering took when lettuce was planted on 20 November which was statistically identical to all other treatments except 10 December. Maximum plant height $(83.8 \mathrm{~cm})$ at flowering stage was recorded from 10 November planting, but it was statistically identical 
to 20 November to 30 November sowing. While the lowest plant height (75.5 $\mathrm{cm}$ ) was on 20 December planting, which was statistically at par with 10 December. Weight of seeds per plant was maximum (28.4g) in 10 November planting, which was statistically similar to 20 November (24.5g) but significantly different from other sowing dates. This might be due to the fact that plants from November planting experienced considerable low temperature during the vegetative growth at the initial stage, as the temperature was probably optimum to fulfill the vernalization requirement of the plants. Begume el al. (1990) also reported that higher seed yield was associated with the increased vegetative growth of cabbage. Significantly the highest germination percentage (75.9\%) was recorded from 10 November. The satisfactory seed yield (770 kg/ha) was obtained from 10 November, which was statistically identical to 20 November $(650 \mathrm{~kg} / \mathrm{ha})$ and statistically differed from all other treatments. There was trend to decrease seed yield with the advance of sowing time. Higher seed yield was recorded at 10 and 20 November sowing due to maximum weight of seeds/plant and favourable temperature prevail during seed production. 30 December planting produced no seed at all due to higher temperature at flowering stage (Fig. 1). Steiner and Opoku-Boateng (1991) also found similar result in lettuce. The effect of plant spacing on lettuce seed production is presented in Table 2. Among the parameters studied, only weight of seeds per plant was significantly affected by plant spacing. Significantly higher seed weight per plant (22.4g) was recorded from $50 \mathrm{~cm} \times 45 \mathrm{~cm}$ spacing compared to the spacing $50 \mathrm{~cm} \times 30 \mathrm{~cm}$ (15.9g/plant).

Temp. ${ }^{\circ} \mathrm{C}$ (Max.) $\square$ Temp. $^{\circ} \mathrm{C}$ (Min.)

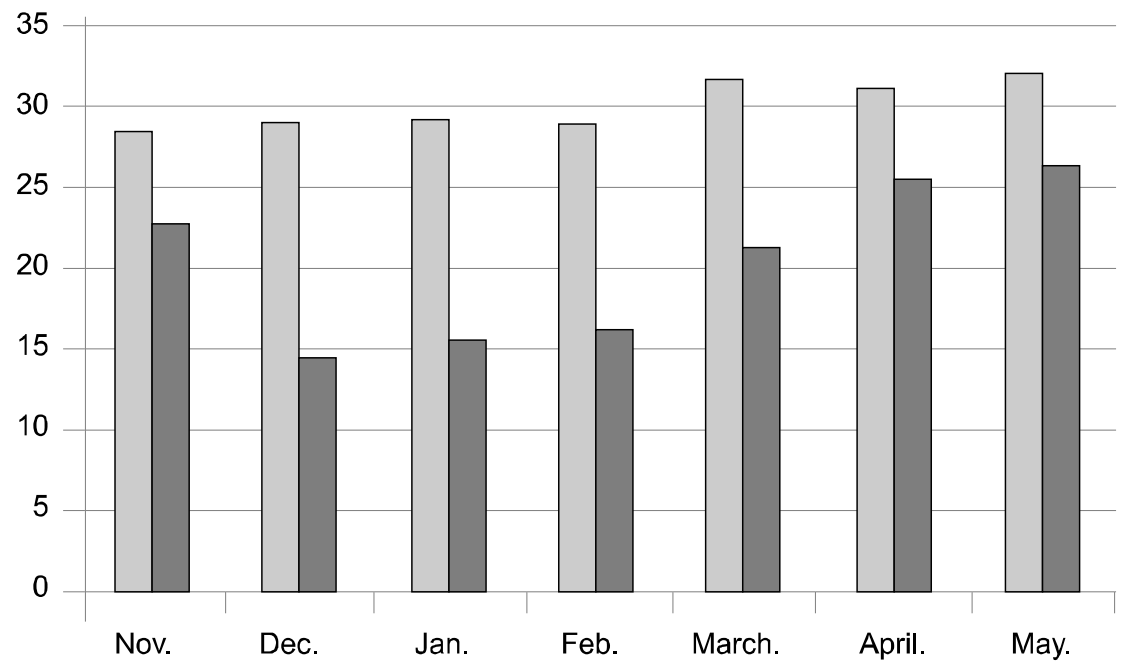

Fig. 1. Temperature of the experiment conducting period. 
Table 2. Main effect of planting time and spacing on lettuce seed production.

\begin{tabular}{|c|c|c|c|c|c|c|}
\hline Treat. & $\begin{array}{l}\text { Days to } 1^{\text {st }} \\
\text { flowering }\end{array}$ & $\begin{array}{l}\text { Plant } \\
\text { height } \\
(\mathrm{cm})\end{array}$ & $\begin{array}{c}\text { Wt of } \\
\text { seeds/ } \\
\text { plant (g) }\end{array}$ & $\begin{array}{l}1000- \\
\text { seed wt } \\
\text { (g) }\end{array}$ & $\begin{array}{c}\text { Germination } \\
\text { (\%) }\end{array}$ & $\begin{array}{l}\text { Seed yield } \\
\text { (kg/ha) }\end{array}$ \\
\hline \multicolumn{7}{|c|}{ Sowing time } \\
\hline 10 Nov. & 83 a & 83.8 a & $28.4 \mathrm{a}$ & 1.2 & 75.9 a & $770 a$ \\
\hline 20 Nov. & 84 a & $83.1 \mathrm{a}$ & 24.5 a & 1.1 & $70.5 b$ & $650 a$ \\
\hline 30 Nov. & 81 a & $82.4 \mathrm{a}$ & $17.3 b$ & 1.0 & $50.4 \mathrm{c}$ & $440 c$ \\
\hline 10 Dec. & 80 a & $77.2 \mathrm{~b}$ & $13.0 \mathrm{c}$ & 1.0 & 51.7c & 350d \\
\hline 20 Dec. & $76 \mathrm{~b}$ & $75.4 \mathrm{~b}$ & $12.7 \mathrm{c}$ & 1.0 & $48.4 c$ & 350d \\
\hline 30 Dec. & - & - & - & - & - & - \\
\hline \multicolumn{7}{|l|}{ Spacing } \\
\hline $50 \times 30 \mathrm{~cm}$ & 81 & 80.1 & $15.9 b$ & 1.0 & 58.9 & 500 \\
\hline $50 \times 45 \mathrm{~cm}$ & 80 & 81.7 & $22.4 \mathrm{a}$ & 1.0 & 59.5 & 520 \\
\hline
\end{tabular}

Means followed by same letter or no letter do not differ significantly at $5 \%$ level by DMRT.

The interaction effect of sowing time and spacing was found significant on days to first flowering, plant height at flowering stage, weight of seeds per plant, germination (\%) and seed yield (Table 3). Maximum time (84 days) required for 10 November planting with $50 \times 30 \mathrm{~cm}$ spacing followed by 20 to 30 November sowing in both spacings. Delayed sowing on 20 December showed 4 to 7 days early flowering in both the spacings. Sowing in 10 November with both the spacings $(50 \times 45 \mathrm{~cm}$ and $50 \times 30 \mathrm{~cm})$ showed maximum plant weight and was significantly different from all other treatments. Weight of seeds per plant was also maximum in 10 November with $50 \times 45 \mathrm{~cm}$ followed by 20 November with same spacing. Germination (\%) was maximum in 10 November sowing with wider spacing $(50 \times 45 \mathrm{~cm})$ was statistically identical with 10 November with closer spacing $(50 \times 30 \mathrm{~cm})$. Seed yield of lettuce was also maximum in 10 November sowing with both the spacings followed by 20 November sowing with $50 \times 45 \mathrm{~cm}$.and $50 \times 30 \mathrm{~cm}$. There was a trend to increase yield upto 20 November sowing and thereafter declined which might be due to temperature effects at flowering stage. Germination (\%) also significantly varied after 10 November sowing in both spacings. 
Table 3. Combined effect of planting time and plant spacing on lettuce seed production.

\begin{tabular}{|c|c|c|c|c|c|c|}
\hline Interaction & $\begin{array}{c}\text { Days to } \\
\text { 1st } \\
\text { flowering }\end{array}$ & $\begin{array}{l}\text { Plant } \\
\text { height } \\
(\mathrm{cm})\end{array}$ & $\begin{array}{c}\text { Wt of } \\
\text { seeds/ } \\
\text { plant (g) }\end{array}$ & $\begin{array}{l}1000- \\
\text { seed wt } \\
\text { (g) }\end{array}$ & $\begin{array}{c}\text { Germination } \\
\text { (\%) }\end{array}$ & $\begin{array}{l}\text { Seed yield } \\
\text { (kg/ha) }\end{array}$ \\
\hline \multicolumn{7}{|l|}{10 Nov. } \\
\hline $50 \times 30 \mathrm{~cm}$ & $84 a$ & 86.la & $23.3 b$ & 1.1 & $75.7 \mathrm{a}$ & $760 a$ \\
\hline $50 \times 45 \mathrm{~cm}$ & 83a & $87.2 \mathrm{a}$ & $33.5 \mathrm{a}$ & 1.2 & $76.1 \mathrm{a}$ & 770 a \\
\hline \multicolumn{7}{|l|}{20 Nov. } \\
\hline $50 \times 30 \mathrm{~cm}$ & $84 a$ & $81.7 b$ & $20.8 b$ & 1.0 & $70.3 b$ & $640 a$ \\
\hline $50 \times 45 \mathrm{~cm}$ & $83 a$ & $84.4 b$ & $28.1 \mathrm{a}$ & 1.1 & $70.7 b$ & $650 a$ \\
\hline \multicolumn{7}{|l|}{30 Nov. } \\
\hline $50 \times 30 \mathrm{~cm}$ & $83 a$ & $81.5 b$ & $15.0 \mathrm{c}$ & 1.0 & $50.3 c$ & $440 \mathrm{~b}$ \\
\hline $50 \times 45 \mathrm{~cm}$ & $80 a$ & $83.2 b$ & $19.5 b$ & 1.0 & $50.5 c$ & $450 \mathrm{~b}$ \\
\hline \multicolumn{7}{|l|}{10 Dec. } \\
\hline $50 \times 30 \mathrm{~cm}$ & $80 a$ & $76.3 c$ & $10.3 d$ & 1.0 & $50.2 \mathrm{c}$ & $340 b$ \\
\hline $50 \times 45 \mathrm{crn}$ & $80 a$ & $78.0 \mathrm{c}$ & $15.7 \mathrm{c}$ & 1.0 & $51.9 c$ & $360 b$ \\
\hline \multicolumn{7}{|l|}{20 Dec. } \\
\hline $50 \times 30 \mathrm{~cm}$ & $77 \mathrm{~b}$ & $75.1 \mathrm{c}$ & 10.ld & 1.0 & $48.3 c$ & $340 \mathrm{~b}$ \\
\hline $50 \times 45 \mathrm{~cm}$ & $76 b$ & 75.7c & $15.3 c$ & 1.0 & $48.4 \mathrm{c}$ & 350b \\
\hline \multicolumn{7}{|l|}{30 Dec. } \\
\hline $50 \times 30 \mathrm{~cm}$ & - & - & - & - & - & - \\
\hline $50 \times 45 \mathrm{~cm}$ & - & - & - & - & - & - \\
\hline CV (\%) & 5.6 & 10.3 & 8.9 & 4.6 & 10.3 & 6.5 \\
\hline
\end{tabular}

Means followed by same letter or no letter do not differ significantly at $5 \%$ level by DMRT.

The results revealed that from 10 to 20 November sowing with wider spacing $(50 \times 45 \mathrm{~cm})$ is found optimum for lettuce seed production in the hilly area.

\section{References}

Aykroyd, W.R. 1963. Composition of dolichas bean green pod. ICMR Special Repor Series No.42

Begume, G, A.Razzaque and M.A. Siddiqu. 1990. Effect of date of planting on the production of cabbage seed. Bangladesh Horticure 18 (1\&2); 39-43

Bose, T. k., M. G. Som and J. Kabir. 1900. Vegetable crops in India. Noya Prokash, Calcuta 70006, India 
Gray, D., D.C.E. Wurr, J.A. Ward and J.R. Fellows. 1988. Influence of post-flowering temperature on seed development and subsequent performance of cris lettuce. Annals of Applied Biology 113: 391-402

Karim, A., H. Y. Nebahat, P. J. Dasjan, D.J. Stoffella. 2000. Effect of sowing dates on seed yield and quality of lettuce in GAP area $8^{\text {th }}$ International Symposium on Timing of Field Production in Vegetable Crops, BARI, Italy, 15-18 October 1997. Acta Hortculturae 533: 39-43

Ryder, E. J. 1998. Lettuce, Endive and Chicory. CABI Publishing Company. USA p.79

Sajjan, A.S., B.S. Vyakarananhal, G. N. Kulkarni. 1992. Effect of date of transplanting and level of fertilizers on seed and yield characters in lettuce. Karnataka J. of Agricultural Science 5(4): 357-361

Steiner, J. R. and K. Opuku- Boateng. 1991. Natural season- long and diural temperature effects on lettuce seed production and quality. J. Am. Soc. Hort. Sci. 116: 396-40.

Verker. K. and C.J.T. Spitters. 1973. Effect of light and temperature on the lettuce seedlings. Netherlands J. of Agricultural Science 21:102-109 